\title{
Observations Concerning the Structure of the Major Salivary Glands in Chinchilla (Chinchilla lanigera)
}

\author{
Bianca MATOSZ, Aurel DAMIAN, Vasile RUS*, Cristian MARTONOS, Adrian GAL, Flavia RUXANDA, \\ Viorel MICLĂUŞ \\ ${ }^{1}$ Faculty of Veterinary Medicine, University of Agricultural Sciences and Veterinary Medicine, Cluj-Napoca, \\ Romania. \\ * Corresponding author: vasilerus2002@yahoo.com
}

Bulletin UASVM Veterinary Medicine 73(1) / 2016,

Print ISSN 1843-5270; Electronic ISSN 1843-5378

DOI:10.15835/buasvmcn-vm: 11814

\begin{abstract}
The structure of the salivary glands is different depending on the species and diet. The glandular secretion can be serous, mucous or mixed. Within the same order, for instance in rodents, there are dissimilarities between the major salivary glands, even if the diet is similar.

In this study, we used three chinchillas, slaughtered for their fur. We harvested the major salivary glands which were histologically processed.

The parotid gland in chinchilla is highly similar to the one in other mammal species, regarding its general microscopic aspect. It contains only one type of acini (serous) and numerous secretory ducts. On the other hand, the submaxillary gland has a particular type of acini, with a narrow lumen and cells with a round nucleus. They resemble the serous ones, but the glanular aspect of the cytoplasm suggests that the secretion of this gland is different in comparison to the one in the parotid gland. The structure of the sublingual gland in chinchilla is similar to the one in most of the mammals, containing typical mucous acini, with a foamy cytoplasm.

The major salivary glands in chinchilla highly resemble those in most of the mammal species. The parotid gland presents serous acini and the sublingual one, typical mixed acini. Instead, the submaxillary gland has a particular aspect: its acini do not present the serous demilune, they resemble the typical serous acini (contain round nuclei), but they are larger.
\end{abstract}

Keywords: Chinchilla, mandibular gland, parotid gland, sublingual gland

\section{INTRODUCTION}

Chinchilla belongs to Mammalia class, Theria subclass, Eutheria group, Rodentia order, Hystricomorpha suborder, Chinchillidae family, Chinchilla species. It is a native rodent from South America. The adults have approximately 25-30 $\mathrm{cm}$ in length, with an average weight of 400-600 grams. They live about 10-15 years (Bura, 2003).

Parotid, mandibular and sublingual glands are major salivary glands. In rodents, topographically, parotid gland lies posterior to the mandibular ramus and anterior to the mastoid process of temporal bone. The mandibular gland is found between atlas and aboral extremity of the mylohyoid muscle, and sublingual gland lies in the vestibular region (between intermandibular symphysis and the first or the second premolar tooth) (Popovici et al., 2003). Structurally, these glands comprise a complex tubular network (gradually branching) and secretory units (acini). The sustaining tissue includes the capsule, septa (which divide the gland in lobes and lobules) and intralobular stroma (Aughey et al., 2001; Bulighescu et al., 1982; Miclăuș, 2012a; Miclăuș, 2012b).

In animals, there are differences between the salivary glands, which depend on species and nutritional type (herbivore, carnivore or 
omnivore). Therefore, both the amount of saliva and its composition differ according to animal's ingest (solid, fluid or semisolid) (Baciu, 1970; Tache, 1994).

Salivary glands' functions include lubricating the first segments of the digestive tube, preparing food for digestion, preserve the integrity of oral mucosa, control the local bacterial flora, facilitate teeth remineralization and neutralize the dental plaque (Gal and Miclăuș, 2013; Tucker and Miletich, 2010; Yasear et al., 2012; Yazdani Moghaddam et al., 2009).

Chinchillas were and still are the object of numerous studies carried out on vascular system (Araújo et al., 2004; Martonos et al., 2014; Ozdemir et al., 2008), nervous system (Bob et al., 2014; Irimescu et al., 2014a; Irimescu et al., 2014b) and also digestive system (Stan, 2013; Stan, 2014).

In published literature, we found little information on chinchilla's salivary glands structure, therefore we assessed them microscopically, aiming to highlight some particular aspects of the major salivary glands, resulted as an adaptation to food and growth conditions of these animals.

\section{MATERIALS AND METHODS}

In this study, we used three healthy chinchillas (approximately 10 months old), from a private breeder in Bistrița-Năsăud county, slaughtered for their fur. We performed a stratigraphic dissection and we isolated the parotid, mandibular and sublingual glands. Subsequently, we harvested the major salivary glands and fixed them in $10 \%$ buffered formalin, dehydrated in ethanol (increasing concentration: $70^{\circ}, 9^{\circ}$, absolute), clarified in n-butanol and embedded in paraffin. We sectioned the tissue at a $5 \mu \mathrm{m}$ thickness, stained the slides with Goldner's trichrome method and examined them with an Olympus BX41 light microscope, equipped with a digital camera.

\section{RESULTS AND DISCUSSION}

The parotid gland in chinchilla is highly similar to the one in other mammal species, regarding its general microscopic aspect. It is a lobulated gland, it contains only one type of acini (serous) and numerous and polymorphic secretory ducts (Fig. 1.). Concerning the general aspect and dimensions, its acini may be compared with those present in other mammals, and the narrow lumen suggests a serous secretion. Particularly, the acinar cells contain a spongy cytoplasm in this species, which could indicate that the secretion is not only proteic, but may have another constituent, possibly lipidic (lipoproteins). This gland is very well vascularized.

On the other hand, the mandibular gland has a particular aspect. It presents the general architecture of the salivary glands, meaning that it is a lobulated gland with the parenchyma formed

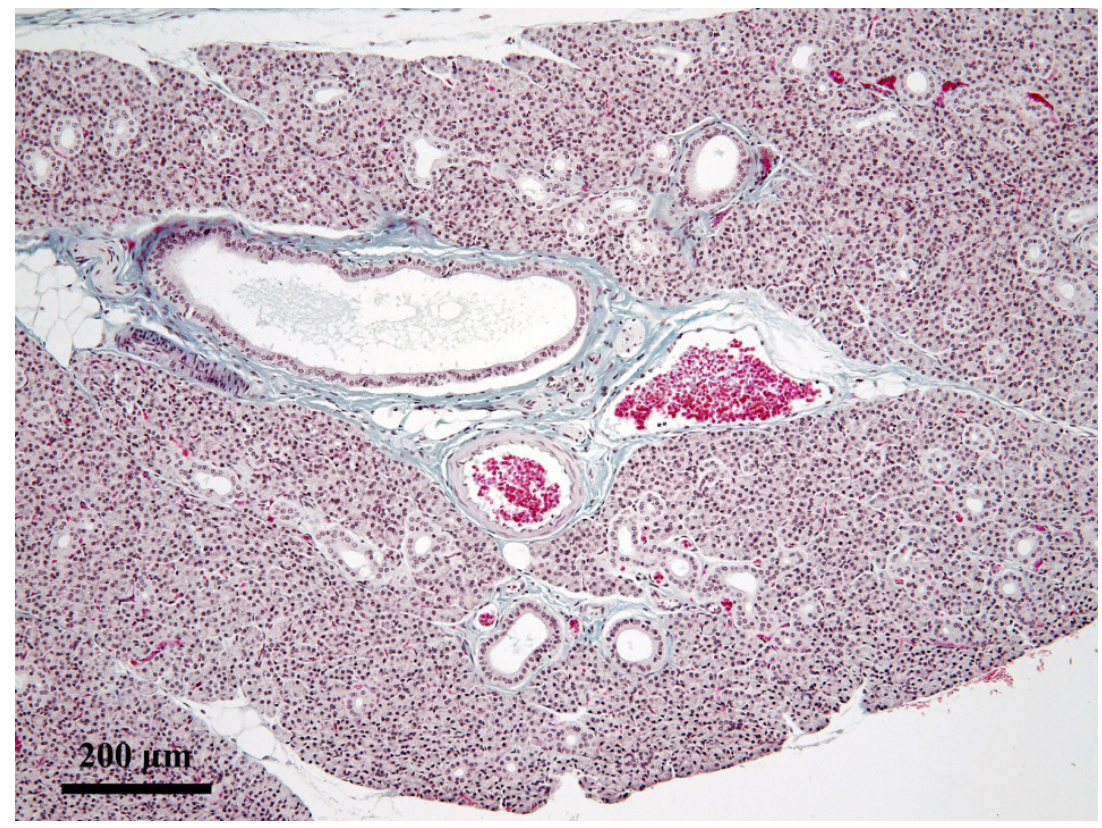

Fig. 1. Parotid gland 
out of acini and excretory ducts. The particularity in this species consists in the fact that there is only one type of acini, while most of the mammals have different types (Fig. 2.). Mixed acini are dominant in most of the species (including humans), whereas in chinchilla acini resemble the serous ones as a general aspect, having a narrow lumen and cells with round nucleus. The difference lies in the slightly larger size of the acini and the granular aspect of the cytoplasm, suggesting that the secretion of this gland is different in comparison to the one in the parotid gland.

Both the histo-architecture and the type of acini in the sublingual gland in chinchilla are similar to the ones in most of the mammals (Fig. 3.). It contains typical mucous acini with mucous cells with flat nuclei, situated at the periphery, same as in other species. The cytoplasm is foamy, vacuolar, suggesting that this secretion is mucous. The lumen is large, meaning that the secretion is even more viscous than in other mammals.

The salivary glands' structure is different depending on species and nutrition. Their secretion may be serous, mixt or mucous (Amano et al., 2012). Structural differences between major salivary glands are found within the same order (rodents for example), even if the food regime is similar.

In rabbit, parotid gland contains serous acini (Al-Saffar and Simawy, 2014; Yasear et al., 2012) and mandibulary gland presents a particularity in comparison with other species, even if it has mixed secretion: it has seromucous acini without serous demilune (Toyoshima and Tandler, 1986). Other authors affirm that normally, rabbit's mandibular gland has mixed secretion, with serous tubes in the proximal portion and seromucous acinar cells in the distal portion (Ahlmer, 1993). In chinchilla instead, mandibular gland contains serous acini. We found that acinar cells in chinchilla have granular cytoplasm, aspect also mentioned by other authors in rabbit's mandibular gland (Ozel et al., 2010). Rabbit's sublingual gland has mostly mucous acini (Al-Saffar and Simawy, 2014).

Parotid and mandibular gland have serous acini in mouse and rat (Amano et al., 2012), aspect also noticed by us in chinchilla. Instead, chinchilla's sublingual gland has mucous acini and mucous secretion type, meanwhile rat and mouse sublingual gland has predominantly mixed acini with mixed secretion (Da Cunha Lima et al., 2004). Salivary glands and acinar dimension in rat differs according to sex. Sublingual gland has smaller mixed and mucous acini in females than in males, and the serous demilune is larger in females ( $\mathrm{Da}$ Cunha Lima et al., 2004), but we did not conduct a comparative study between sexes, thus we cannot report any differences.

Hamster's parotid gland contains serous acini. Mandibular gland is mixed, having serous and

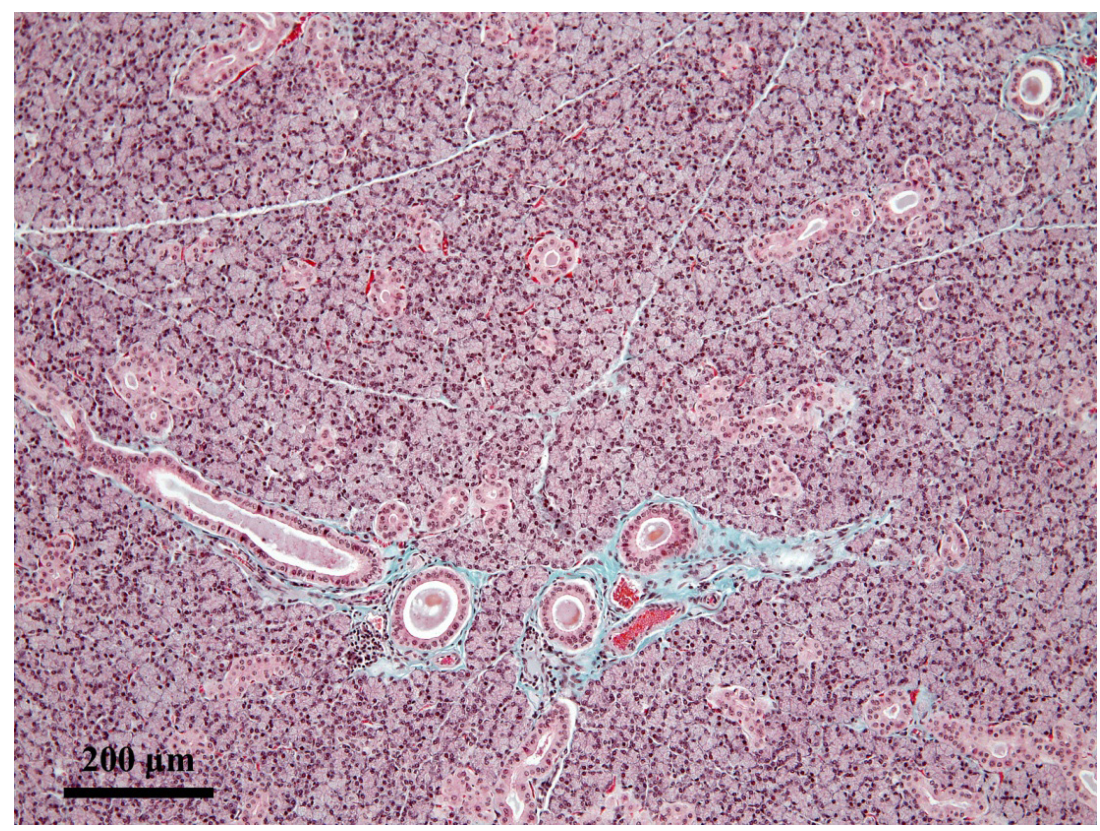

Fig. 2. Mandibular gland 


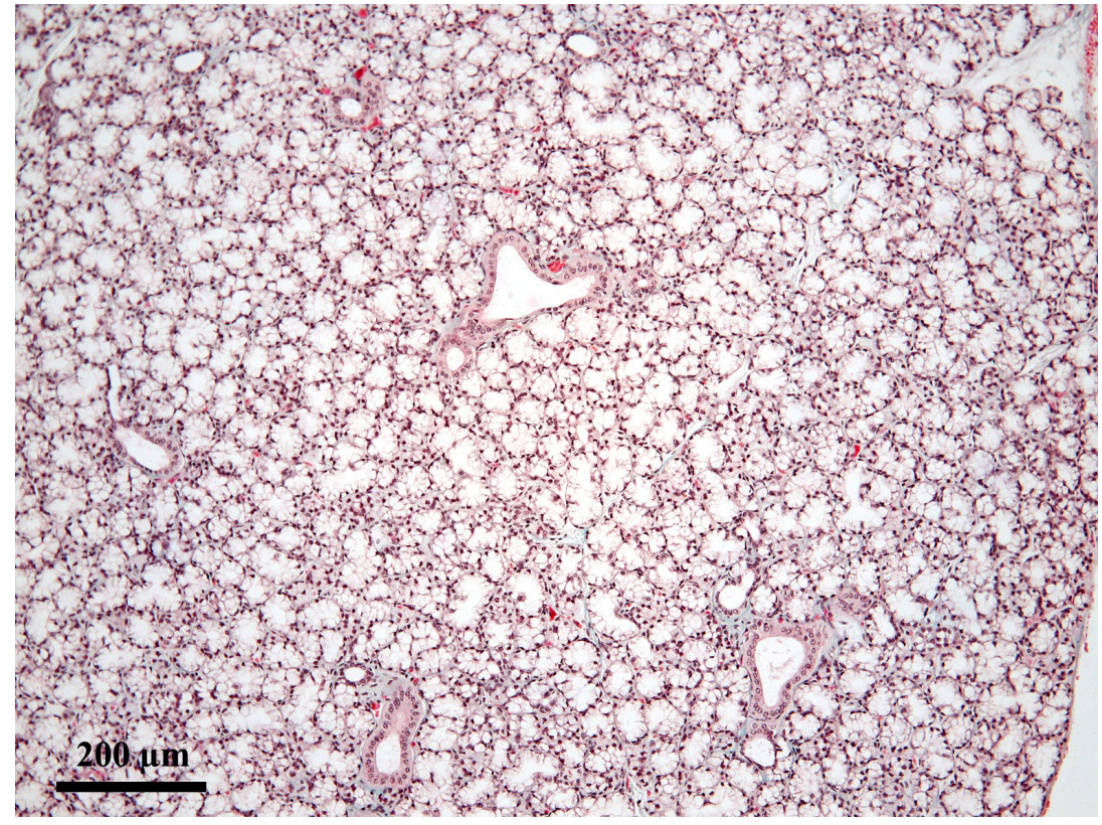

Fig. 3. Sublingual gland

mixed acini, with serous demilune (Khojasteh and Delashoub, 2012). Other rodent species have the same type of secretion: Nesokia indica, Cricetus migrator, Allactaga elater, Funambulus pennati and Meriones libycus (Khojasteh and Delashoub, 2012). Instead, we found that chinchillas' mandibular gland contains only serous acini, just like Jaculus blanfordi (Yazdani Moghaddam et al., 2009).

Seems like the differences between mandibular glands in rodents might be associated with nutrition characteristics. Presumably, the histologic diversity of the mandibular gland resides in the difference between the lifestyle among rodents (Yazdani Moghaddam et al., 2009).

\section{CONCLUSION}

Regarding the general histo-architecture, the major salivary glands in chinchilla highly resemble those in most of the mammal species. They present acini and numerous excretory ducts.

As for the secretion type, the parotid gland presents serous acini and the sublingual one, mucous acini. On the other hand, the mandibular gland has a particular aspect in comparison to that in the majority of mammals. Its acini do not present the serous demilune and they resemble the typical serous acini (contain round nuclei), but their size is larger.

\section{REFERENCES}

1. Ahlmer BH (1993). Irradiation of rabbit submandibular glands. Acta Otolaryngol 113:210-19.

2. Al-Saffar FJ, Simawy MSH (2014). Histomorphological and histochemical study of the major salivary glands of adult local rabbits. International Journal of Advanced Research 2(11):378-402.

3. Amano 0, Mizobe K, Yasuhiko B, Sakiyama K (2012). Anatomy and Histology of Rodent and Human Major Salivary Glands. Intl Res J Appl Basic Sci 3(7):1544-1548.

4. Araújo ACP, Oliveira JCD, Campos R (2004). Ramos colaterais do arco aórtico e suas principais ramificações em chinchila (Chinchilla lanigera). Revista Portuguesa de Ciências Veterinárias 99:53-58.

5. Aughey E, Frye FL (2001). Comparative veterinary histology with clinical correlates. Iowa State University Press, Ames.

6. Baciu I (1970). Fiziologie. Editura Didactică și Pedagogică, București.

7. Bob D, Irimescu I, Ghiurco FI, Stan FG, Chende A, Damian A (2014). The anatomical study of the spinal cord in chinchillas (Chinchilla lanigera). Anatomia, Histologia, Embryologia 43(1):25.

8. Bulighescu L, Gheorghescu B, Puşcaş I, Exarcu IT (1982). Fiziologia şi fiziopatologia digestiei. Medicală, București.

9. Bura M (2003). Chinchilla. Agroprint, Timişoara.

10. Da Cunha Lima M, Sottovia-Filho D, Cestari TM, Taga $\mathrm{R}$ (2004). Morphometric characterization of sexual differences in the rat sublingual gland. Braz Oral Res 18(1):53-8.

11. Gal F, Miclăuş V (2013). Histology. Risoprint, Cluj-Napoca.

12. Irimescu I, Bolfă PF, Vidrighinescu R, Crişan M, Dezdrobitu CC, Damian A (2014b). Preliminary results of a macroscopical and histological study of the medulla 
oblongata in chinchillas (Chinchilla lanigera). Anatomia, Histologia, Embryologia 43(1):54.

13. Irimescu I, Chende A, Ghiurco F, Damian A (2014a). Anatomical Study of the Cerebral Hemispheres in the Chinchilla (Chinchilla lanigera). Bulletin UASVM Veterinary Medicine 71(1):130-136.

14. Khojasteh SMB, Delashoub M (2012). Microscopic anatomy of the parotid and submandibular salivary glands in European hamster (Cricetus cricetus L.). International Research Journal of Applied and Basic Sciences 3(7):15441548.

15. Martonos C, Dezdrobitu C, Rus V, Miclăuş V, Irimescu I, Damian A (2014). Distribution of the Terminals of the Descending Abdominal Aorta in Chinchillas. Bulletin UASVM Veterinary Medicine 71(2):371-376.

16. Miclăuş V (2012a). Biologie celulară şi histologie generală. Ediţia a II-a revizuită, Risoprint, Cluj-Napoca.

17. Miclăuş V (2012b). Histologie specială şi embriologie generală. Ediţia a II-a, Risoprint, Cluj-Napoca.

18. Ozdemir V, Çevik-Demirkan A, Türkmenoğlu I (2008). Subgross and Macroscopic Investigation of Blood Vessels Originating from Aortic Arch in the Chinchilla (Chinchilla lanigera). Anatomia, Histologia, Embryologia 37:131-133.

19. Özel O, Ayçiçek A, Kenar F, Aktepe F, Sargin R, Yilmaz MD, Dereköy FS (2010). Histopathologic changes in the rabbit submandibular gland after 5-fluorouracil chemotherapy. Turk J Med Sci 40(2): 213-220.
20. Popovici I, Damian A, Popovici N, Chirilean I (2003). Tratat de anatomie comparată- Splanhnologie. Academic Press, Cluj-Napoca.

21. Stan F (2013). Comparative study of the stomach morphology in rabbit and chinchilla. AgroLife Scientific Journal 2(2):73-78.

22. Stan F (2014). Anatomical particularities of the cecum in rabbits and chinchillas. Bulletin UASVM Veterinary Medicine 71(2):406-412.

23. Tache S (1994). Fiziologia glandelor salivare. Dacia, ClujNapoca.

24. Toyoshima K, Tandler B (1986). Ultrastructure of the submandibular gland in the rabbit. General Histology and Cytology, Cleveland.

25. Tucker A, Miletich I (2010). Salivary glands- development, adaptations and disease. Karger, London.

26. Yasear AY, El-Ramli A, Sultan A, Hussein AH (2012). Histological changes in the parotid salivary gland of rabbit treated with neostigmine. Karbala J Med 5(1):1396-1405.

27. Yazdani Moghaddam F, Darvish J, Mahdavi Shahri N, Abdulamir AS, Mousavi M, Daud SK (2009). Comparative histological and histochemical inter-species investigation of mammalian submandibular salivary glands. Res J Appl Sci 4:50-56. 